The Third Pole: Journal of Geography

Vol. 20 - 21: 101-110, 2021

DOI: https://doi.org/10.3126/ttp.v21i01.41622

Department of Geography Education,

Central Department of Education, T.U., Kathmandu, Nepal

\title{
PLACE OF GEOGRAPHY IN SCHOOL LEVEL CURRICULUM
}

\section{Suman Kumar Shrestha ${ }^{1}$}

\section{Abstract}

This paper examines the place of geography in the school-level curriculum in Nepal. The rearm curriculum defines as the totality of student experiences that occur in the educational process. Specifically, it is referred to a planned sequence of instruction, or a view of the student'; experiences in terms of the educator; or school's; instructional goals. After the establishment of Durbar High School in Nepal in 1910 and the School Leaving Certificate Board in 1990, the subject of Geography was formally introduced. This subject had recognized as a compulsory subject at the school level curriculum before the NESP. After the NESP (1971), the issue had allocated 50 marks, becoming has becomes an optional subject since 1982. Geographic concepts have been taught after the introduction of the social studies curriculum at the secondary level since 1992. At present, geography is teaching in Nepal as an elective subject from secondary level to higher education. However, this subject seems less of a priority for students than mathematics, computer, and account. For this purpose, data collected from the review of the report published from the Education Commissions, Curriculum Development Center, the records of the National Examination Board, e-resources, and other concerned bodies. This paper concludes that geography subject at the school level is in a crisis. However, with the inclusion of geographic information systems (GIS) and spatial planning in the curriculum from the school level, the future of this subject looks bright.

Keywords: Geography, curriculum, human-environment, spatial planning, social studies.

\section{Introduction}

'Geography is the study of the earth, its inhabitants and the interrelationships between them in the context of place, space and environment. It is concerned with the nature, distribution and interaction of human and natural features over the earth's surface, the processes, which create, sustain or change these features, and the contribution they make to the distinctive character of places' (GoI, 1999, p. 6).

1 Shrestha is a Lecturer, Sanothimi Campus, Bhaktapur, email: shresthasuman1971@gmail.com 
Understanding geography tries to find the answer to the following question: where were things are found. Why are they there? In addition, how do they develop and change over time? (AAG, 2020). The answer to these questions is not possible from the understanding of a single subject. Therefore, the subject matter of geography has derived from different subjects. It integrates both natural and social sciences in the curriculum at different levels. The government of Ireland (GoI) revealed that geography subject plays a significant role in the school curriculum. The geography curriculum is designed to reflect the diversity of the subject, to encourage a balance between the acquisition of skills and knowledge, and to draw attention to the essential, critical values and attitudes related to geography (GoI, 1999).

The study of geography imparts knowledge and skills related to the local environment to the children. It helps children to make sense of their surroundings and the wider world. They understand the natural and human processes and patterns present in these environments, and they can learn to appreciate the similarities and differences between places. It also provides opportunities to acquire a range of investigative, graphical, and other skills. Thus, geography encourages children to promote understanding of, and respect for, the cultures and ways of life of peoples throughout the world. It fosters an informed sense of individual and community responsibility for environmental care (Graves, 1996; Andrew, 1996; GoI, 1999).

Henson and Savage (2015) define curriculum as an overall plan for learning (p. 15). However, as noted earlier, the same authors also describe curriculum as the specification of skills and content to be taught (p. 58).

A curriculum usually contains a statement of aims and specific objectives; it indicates some selection and organization of content learning and teaching, whether because the goal, purposes demand them or because the content organization requires them.

Thus, the school-level curriculum should cover geographic concepts, theories, and themes while preparing the curriculum. However, the formulation of geography curriculum was a more complicated process than merely selecting appropriate content from a discipline even if that content (defined as the concepts, principles, and competencies of that discipline) is brought up to date from time to time with its evolution (Graves, 1996). Geography students need to be sufficiently competent in geography languages, not necessarily in a general sense, but primarily in the technical terminology, methods of argument, and methods (Andrew, 1996). The government policies towards the structure and balance of curriculum are essential to implement and continue curriculum (Rawling, 1996). 
Suman Kumar Shrestha / Place of Geography in School level Curriculum ||103 ||

The Curriculum Development Committees formed by UGC under the leadership of Nangia expressed such views on the subject of geography in India (Nangia, 2001). The up-gradation and reframing of the syllabi has designed to keep in view the dimensions of change in knowledge, attitude, and technology. The contents of the courses have been upgraded and introduced an expanded understanding of physical geography, human geography, and regional geography, application of information communication technology, and fieldwork (p. 2). This statement further confirms the importance of the geography subject of the Curriculum Development Committee at different levels.

Understanding of philosophy and practice directs the discipline of geography conceptually and practically towards progressive social change by elaborating explicit experiences of the complexity of our spatial world (Aitken and Valentine, 2006).

It shows that the geography curriculum incorporated new knowledge, new multidisciplinary frontiers, and better access to knowledge through information technology. This subject has further enhanced the interdisciplinary competitive knowledge for acquiring academic and practical knowledge of developing countries like Nepal

Burathoki (1993) argued that teaching geography had achieved a significant place in the educational system. It teaches us how to live and exist in perfect harmony, adopt ourselves to our environment, and the most valuable and exciting things of cultural value. According to him, the first principle of teaching geography is that knowledge is not being forced upon the pupil. The second principle of successful teaching is the art, or method, of subject presentation. A third important principle in teaching geography is the stimulation of physical activity and mental activity i.e., active participation. He also believed that the curriculum includes active like any other and store the knowledge and facts of geographic experience at the primary school level. The content of geography in a school should start from studying ones' immediate neighborhood for the realization and the actual development of geographical sense. His emphasis was on the study of home geography, fieldwork, and excursion. Thus, the geography teacher must develop a new idea, the fundamental philosophy of geography, i.e., a perfect understanding of humanity as a whole so that the present and coming generation in the atomic age can live in perfect harmony, mutual understanding, and peace. A friendly knowledge between individuals and nations is essential for the good of humanity.

In Nepal, geography has considered as an oldest academic discipline at both the school and university levels. The history of geography as an academic field of study dates back to the beginning of the 20th century in Nepal. However, the use of geographic ideas, concepts, and geographical descriptions of the place go to the Vedic period (Subedi \& 
Poudel, 2005). Jay Prithivi Bahadur Singh was the person who introduced geography in 1901 in the school level curriculum first time. Then, geography developed as an organized subject after the establishment of the SLC board in 1934 enhanced the popularity of this discipline at the school level (Khatiwada, 2019; Adhikari, 2010). Nevertheless, in the early days, school and university-level geography curriculum seemed to be guided by the Indian curriculum in Nepal.

This subject had recognized as a compulsory subject before the NESP in 1971. However, it was limited to 50 marks after the implementation of NESP, and it has become an optional subject since 1982. Geographic concepts have taught after introducing the social studies curriculum at the secondary level since 1992. However, the social studies do not cover all the subject matters of geography. At present, geography is teaching in Nepal as an elective subject from secondary level to higher education. The place of geography curriculum marginalized as one of the subjects in the least favored optional category, and the provision competed with mathematics and science (Subedi\& Joshi, 1997). Thus, there is always a lack of geography in the school curriculum. Therefore, genius students did not offer geography, and this discipline faced setback.

In addition to this, the High-Level Education Commission formed at different times, the government policy, and the various donor agencies' reports suggested to improve the quality of education, but implementation of these recommendations seem to be deteriorated the place of geography in school curriculum. Thus, it requires further clarification and a critical analysis of place of geography in the school-level curriculum in changing circumstances.

\section{Method and Materials}

This paper based on the reviews of secondary sources of data. Necessary data were collected from different journals, books and e-resources. The published and unpublished documents of the Curriculum Development Center (CDC), the reports of the High-Level Education Commission, reports of the various donor agencies, and Periodic Plans were sources of information. The data of student numbers were collected from the official records of the National Examination Board.

\section{Results and Discussions}

Historical Development of curriculum in Nepal: The opening of the Durbar High School (1854) and establishment of the School Leaving Certificate (SLC) Board (1990) have credited to the formal geography education at the school level in Nepal. However, teaching geographic concepts has initiated through the Vedic Periods (Subedi \& Poudel, 
Suman Kumar Shrestha / Place of Geography in School level Curriculum ||105 ||

2005). Jaya Prithvi Bahadur Singh has often credited with the initiation of geography education at the school level in Nepal. The subject started at the college level only with the establishment of the geography department at Trichandra College (1947), and College of Education (1956). It shows that formal geography teaching seems to have started even before the establishment of Tribhuvan University.

The subjects like history and geography have taught at the school level since the National Education System Plan 1971. In addition, it was a part of the Social Studies curriculum after 1992. The Government of Nepal published a National Curriculum Framework (NCF) in 2017 after the promulgation of the constitution in Nepal (2015). It seems to have advanced the three-tier educational systems, namely basic (primary), secondary level schools, and higher education. The school system was structured eight years of basic (primary) school, and four years of secondary levels. In the National Curriculum Framework (2017), Social Studies were considered the most essential subject, known as a core subject at the school level. The social studies curriculum comprises five thematic areas, including the subject of geography, history, and civics. Today, the Government of Nepal has made arrangements for the study of Geography as an optional subject at secondary (grades 9-12) and higher levels. The main contents of the geography curriculum are teaching as the roots of the compulsory and optional subjects in Nepal. The contents have arranged as a part of the social studies curriculum and subjective specific contents in optional subjects. For example, the content more focused on the integration of local geography in the early basic level (Grade 1-3) with other issues, and Nepalese and world geography in Grade 4-8, and world geography comprises the main contents in secondary level (Grade 9-12). The geography curriculum includes physical, human, economic, regional, fieldwork, tools, and techniques at higher levels. The content has been also offered in the teacher service commission curriculum, teachers' license, and teacher training manual for in-service or novice teacher training.

The Place of Geography at Primary and Lower Secondary Level: After the democracy in Nepal (1950), the recommendation of the Higher Education Commission recommended the place of geography subject in social studies curriculum 20 percent and 13 percent of the total school hours and 100 marks in primary and lower secondary levels curriculum respectively. The implementation of this recommendation had shrinkage the place of geography in Primary and Lower Secondary level curriculums. NESP (1971) seems to have continued this recommendation at the primary and lower levels, and the geographic concepts are placed entitled in understanding our earth'. The curriculum covers physical geography, human geography, regional geography, map making, field study, etc. The geographical concepts taught through an integrated approach up to the Grade 1-3 curriculum. 


\section{||106 || The Third Pole: Journal of Geography, Volume 20 - 21, 2021}

Geography Curriculum at Secondary Level: After the recommendation of the first education Commission report, geography seems to have become a compulsory subject at the secondary level. NESP (1971) also recognized geography as a mandatory subject included in the secondary level of the 6\% school hours and 50 marks out of 900 fullmarks. Geography has appeared as an optional subject of 100 marks with the revision of the NESP curriculum in 1982. The structure of the curriculum did not change much since 1982-1990. However, the government of Nepal launched bilateral and multilateral educational reform programs with the support of various donor agencies.

Geography Curriculum after 1990: After the restoration of the multi-party political system, the government has been a radical change in the structure and curriculum of the school level after the recommendation of the higher-level education commission report in 1992. This change does not seem to have significantly improved the place of geography in school curricula (Table 1). The geographic concepts taught mandatorily under the heading of understanding our earth in the social studies curriculum. The subject matters in the social studies curriculum are derived from different areas physical, human, economic, regional, map work, field studies. Social studies subject covers the following geographic concepts in the Grade 9 and 10 curricula. They are physical features of the planet, climates, and impact of climatic elements, geo-economic activities of continents, problems of population growth and migration, and the impact of landslides on the physical features of Nepal. In addition, different zones and development regions, agricultural production in the various geographical areas, drawing a map of Nepal, and filling in the main industrial centers and roads, field studies, data analysis, and presentation in charts, and location of historical sites in a map.

Table 1: Subjects and weightage of secondary curriculum (Class 9 and 10)

\begin{tabular}{|l|l|l|}
\hline \multirow{2}{*}{ Subjects } & Class 9 and 10 \\
\cline { 2 - 3 } & Weightage & Full Mark \\
\hline Nepali & 5 & 100 \\
\hline Mathematics & 5 & 100 \\
\hline English & 5 & 100 \\
\hline Science & 5 & 100 \\
\hline Social studies & 5 & 100 \\
\hline Health, Population and Environment Education & 4 & 100 \\
\hline Optional Paper-I & 5 & 100 \\
\hline Optional Paper - II & 5 & 100 \\
\hline Total & 39 & 800 \\
\hline
\end{tabular}

Source: Nepal Education policies, curriculum design and implementation at the general secondary level, (n. d.), p. 105 
The optional subjects are grouped into languages, humanities, social science, and optional mathematics in group A and interdisciplinary subject such as agricultural education, food science, architectural education, industrial education, and so on in group B (Table 1).

Impact of Liberal Policies in Geography Curriculum: Neoliberalism has become the dominant socio-economic paradigm in Nepal after the restoration of multi-party democracy. It has had a tremendous impact on all aspects of our lives after adopting the liberal policy by the elected government since 1990. The economic and political dimensions of liberalism seem to have impacted the education sector as well in Nepal. However, a lack of analysis occurred of the effects of liberal policy for the flourish of geography at different levels. After adopting the liberal policies, our core educational functions of the institution are transformed into commodities, which sold on the open market, which leads to an emphasis on competition, measurement, assessment, and an unyielding focus on money. At a time, information and technology are making the world closer to each other. The subject who does not immediately sell their products in the market began to fall into the trap. Instead, the private and community schools and colleges have not opened geography as an elective subject due to the provision of expenses. As a result, the number of students has been decreasing at the school level. They have given pace either optional mathematics of accounts or others from Group A stated in Table 1.

Nowadays, geographic information systems (GIS) seem to be an emerging marketable subject, but geography subjects could not expand the GIS in the school-level curriculum. At the same time, there is a lack of publicity on the importance of geography, and GIS technology in the contribution of national development seems to be weakening the position of geography at both school and higher levels. Thus, the place of geography curriculum become marginal as one of the subjects in the least favored optional category, and the provision competed with mathematics and science (Subedi \& Joshi, 1997).

National Curriculum Framework: The national curriculum framework updated the school-level curriculum based on the federal structure of the country in 2019. The recommendations of the national curriculum framework made social studies and lifeskill education a mandatory subject for Grade 11 and 12 . These subjects have also addressed some of the geographic topics under geography and social relationship in the curriculum.

Table 2 shows the student enrolment in geography in grades 11 and 12 . The result indicates that 95 students majoring in geography in 2076/77 B. S. and it was 131 2072/73 B. S. in Nepal. This figure revealed that 3 percent of students decreased annually within five years. 
|| 108 || The Third Pole: Journal of Geography, Volume 20 - 21, 2021

Table 2: Student enrollments in Grade 11 and 12

\begin{tabular}{|l|l|l|l|l|l|}
\hline Grade & $2072 / 73$ & $2073 / 74$ & $2074 / 75$ & $2075 / 76$ & $2076 / 77$ \\
\hline 11 & 68 & 58 & 52 & 49 & 46 \\
\hline 12 & 63 & 67 & 58 & 52 & 49 \\
\hline
\end{tabular}

Source: GoN, 2020.

Table 2 shows the number of students enrolled in geography has been decreased from $2072 / 72$ to 2076/77. The institutionalization of geography as an academic discipline was considered crucial for organizing meetings and conferences, increasing networking opportunities among geographers, and developing relations with public and governmental institutions. Besides, geographers have complained about the lack of platforms for discussion and debate geographical research. In this regard, Janwali et al. (2015) recommended that the school-level geography curriculum be explored equally as the location. Their institutional research findings indicate a strong need for making geography a compulsory subject at the school level. It requires a marketable curriculum that creates jobs, management of effective teaching with monitoring and evaluation, and refresher training for teachers to enhance geography education as a discipline. Other factors competency in contents, technical terminology, methods, languages, and government policies are equally crucial to the continuity of the curriculum (Graves, 1996; Andrew, 1996; Rawling, 1996).

Thus, Graves (1996) suggests that the geography curriculum must result from the interaction of the curriculum process should be outlined:

1. The general objectives to be used in the geography content (concepts, principles, and skills, not facts) need to be selected in the light of the public education aims agreed for the national education system. Inevitably, these objectives will be achieved according to the intellectual development of the students at different levels of the school.

2. To large extent, what is feasible at any level is something that teachers learn from their evaluation of the progress made by their pupils through psychological knowledge of mental development.

3. The teaching strategies used; need to be in harmony with the objectives set. Thus if one of the objectives is to develop the ability to make decisions in urban planning, there is no point in getting pupils to learn a ready-made solution to the problem. Thus teaching strategies depend on what objectives is set, and conversely, teaching methods that are appealing to teachers and students inevitably affect the type of objectives. 
4. The selection of content is dependent on the general objectives aimed. Therefore, only those parts of the discipline that are supposed to fulfill these general objectives will be selected, and those elements of the content will become the specific objectives, lessons or teaching units that form the basis of the teachers.

Thus, ultimately much depends on what is seeing as the aims of educationand within these the general objectives of geographical education. The effect will considerably reduce the content of what is teach, to enable a deepening ofunderstanding and an increased capacity to use tools of the geographer.

\section{Conclusion}

This study concludes that geography is a necessary discipline and mother science for all educational fields. In the case of Nepalese school educational practices, geography subject was prioritized as a compulsory subject after the establishment of the SLC board in 1990. Still later wards National Education System Plan, 1971 included geography subject into social science subject and gave the least priority as compared to other issues. Even at present, Secondary Education Curricula, 2076 also has included geography subject into critical social studies subject studying in grade one to twelve. At the same time, this subject became compulsory in grade eleven. Owing to that, students'; enrollment in this subject is decreasing annually; the concerned stakeholders must realize that as an educational issue. Hence, geography subjects should include the local level, province, and federal geographical units according to the geographical restructuring of the nation. Similarly, most of the schools (both community and institutional) have computer lab facilities that can offer GIS programs is introduced at the university level. If so, schoollevel students' interest in geography subjects will increase.

\section{References}

Adhikari, J. (2010). Geographical education and research in Nepal. Kathmandu: Social Science Baha Occasional Paper 3.

Andrew, C. (1996). 'Appropriate language competence for geographers: French. In: Géographesassociés $n^{\circ} 18$, 1er semester Le Géoforum Franco-Britannique de Rouen. Libresdébats sur les géographiesbritanniqueetfrançaise. pp. 91-92; doi https://doi.org/10.3406/geoas.

Aitken, S., and Valentine, G. (2006). Approaches to human geography. London, UK: Sage. Burathoky, J. B. (1993). The teaching of geography in our schools. The Geographers' Point, 2 (2), pp. 22-26. Kathmandu: Centre for Nepalese Geography. 
|| 110 || The Third Pole: Journal of Geography, Volume 20 - 21, 2021

CDC (2014). Secondary School Curriculum Class 9-10, 2014(Madhyamik Sikshya Pathyakram Katshya 9-10, 2071 B.S.). Bhaktapur: Curriculum Development Center, Ministry of Education, Government of Nepal.

CDC, (2019). Secondary School Curriculum. Bhaktapur: Curriculum Development Center. GoI (1999). Geography: Social, environmental, and scientific education curriculum.

Dublin: Government Publications, Government of Ireland.

GovN (2020). National Examination Board. Bhaktapur: National Examination Board, Government of Nepal.

GovN (2018). Higher - level National Education Commission, Report. Kathmandu: Government of Nepal.

Graves, N. J. (1996). The formulation of a geography curriculum. In Géographesassociés $n^{\circ} 18$, 1er semestreLeGéoforum Franco-Britannique de Rouen. Libresdébats sur les géographiesbritanniqueetfrançaise. pp. 87-89; doi :https://doi.org/10.3406/ geoas. 1996.2020

Janwali, D., Poudel, K. P., Rijal, S. P., Dhakal, K. R., Awasrhi, T. P., \& Sigdel, T. P. (2015). Geography education in Nepal has some issues and challenges. Nepalese Journal of Educational Studies: A publication of central Department of Education, 2 (1), pp. 15-24.

Khatiwada, S.P. (2019). Status and barriers of classroom-based student assessment practices in geography at secondary level in Nepal. Interdisciplinary Research in Education, 4 (2), pp. 123-131, https//doi.org/10.3126/ire.c4i2.27935.

Nangia, S. (2001). Curriculum Development Committee in Geography. India: CDC in Geography.

Rawling, E. M. (1996). Changing geography in schools: Some issues for higher education. The experience of England and Wales. In: Géographesassociés $n^{\circ} 18$, ler semestre. Le Géoforum Franco-Britannique de Rouen. Libresdébats sur les géographiesbritannique et française. pp. 97-105; doi :https://doi.org/10.3406/ geoas. 1996.2023

Subedi, B. P. (2014). The state of geography teaching and research in Nepal: A review and reflection. Kathmandu: Martin Chautari.

Subedi, B.P. \& Joshi. B. D. (1997). About geography in Nepal: An outline for discussion. In Prem K. Katry ed.), Social sciences in Nepal: Some thoughts and search for direction. Kathmandu: Center for Nepal and Asian Studies. pp. 90-112.

Subedi, B. P. \& Poudel, P. C. (2005). Geography and geographers work in Nepal: An introduction. In Subedi, B. P. \&Poudel, P.C (eds.), Geography and geographers work in Nepal: Reflections on mountain environment and human activities. Kathmandu: Nepal Geographical Society, Central Department of Geography and National Center of Competence in Research, pp. 1-10. 